\title{
EVALUATION OF RISK VALUE OF INVESTORS OF PROJECTS FOR THE CREATION OF CROP PROTECTION OF FAMILY DAIRY FARMS
}

\author{
Anatoliy Tryhuba ${ }^{1}$, Vitalij Boyarchuk¹, Inna Tryhuba², Oleh Boyarchuk, \\ Oksana Ftoma ${ }^{3}$ \\ ${ }^{1}$ Faculty of Mechanics and Power Engineering, Lviv National Agrarian University, str. Vladimir the Great, 1, \\ Dublyany, Zhovkva district, Lviv region, 80381, Ukraine \\ 2 Faculty of of Agrotechnology and Ecology, Lviv National Agrarian University, str. Vladimir the Great, 1, Dublyany, \\ Zhovkva district, Lviv region, 80381, Ukraine \\ ${ }^{3}$ Faculty of Economics, Lviv National Agrarian University, str. Vladimir the Great, 1, Dublyany, Zhovkva district, \\ Lviv region, 80381, Ukraine
}

To link to this article: https://doi.org/10.11118/actaun201967051357

Received: 29. 9. 2018, Accepted: 20. 8. 2019

To cite this article: TRYHUBA ANATOLIY, BOYARCHUK VITALIJ, TRYHUBA INNA, BOYARCHUK OLEH, FTOMA OKSANA. 2019. Evaluation of risk value of investors of projects for the creation of crop protection of family dairy farms. Acta Universitatis Agriculturae et Silviculturae Mendelianae Brunensis, 67(5): 1357-1367.

\begin{abstract}
The analysis of the status and trends of the development of territorial communities in Ukraine is carried out. The expediency of the development of tools for assessing the risk of investors' value in projects for the creation of cooperatives for the provision of family dairy farms is substantiated. The model and computer program of risk assessment of investors' value of projects based on the use of probability theory, methods of mathematical statistics and modeling of work execution for determination of variable costs for feed production are developed. It has been established that there are three scenarios for the formation of the value of investors for the creation of FC projects and three zones of their risk. The initial data are grounded for assessing the risk of investors investing in projects for the creation of cooperatives for the provision of family dairy farms. The study of the characteristics of the project environment for the conditions of the "Pokrova" SOK has been performed, which is located on the territory of the Zabolotiv's community of the Brody district of the Lviv region. The statistical characteristics of distribution of expenses for production of feed, their market value and profit of investors of cooperatives forage supply of family dairy farms are substantiated. The level of risk of obtaining value from investments in the project of establishing a cooperative of forage provision of family dairy farms with a given minimum value of their profit is determined.
\end{abstract}

Keywords: risk, value, investors, projects, creation of cooperatives, feed production, family dairy farms

\section{INTRODUCTION}

The current problem of Ukraine's food security is multifaceted and concerns the production of raw materials and food of various kinds. One of the most important components of this problem is to ensure the production of quality dairy products (Tryhuba, 2015). The vast majority of raw milk is produced on the territory of newly created communities, in the households. Strengthening the requirements of the EU and our country for the quality of raw milk determines the members of the communities on which milk is produced from raw materials, merged into family dairy farms (FDF), through the implementation of relevant projects (Tryhuba, 
2014). The implementation of such projects enables the FDF to provide a number of necessary resources (production facilities, machinery and equipment, performers, etc.), which greatly improves the quality of raw milk produced, and, accordingly, their value. At the same time, scientific and applied problems of provision of FDF by feed are still unresolved, which requires the implementation of projects for the establishment of feed-cooperatives (FC) of these farms. At the same time, the production of quality feed significantly affects both the quality of raw milk production and the value of creating FDF (Tryhuba et al., 2015).

Taking into account the unsatisfactory financial situation of territorial communities, there is a need to attract investments in the projects of creation of the FC (Vasylieva, 2016). Each investor wants to know the projected value of investment in these projects (Teslya et al., 2016). The value of projects refers to the benefits received by interested parties (stakeholders) from their product (Bushuyev et al., 2010). However, existing tools for evaluating the value of projects can not be used to assess the value of investors in drafting FC projects. In particular, they do not take into account both the features of these projects, as well as the presence of a number of changing components of the project environment, which determines their risk. In order to assess the value of investors in FC projects, methods and models that will take into account both the features of their project environment (changing climatic conditions, feed production, market value, etc.) and the risk of its components should be used. This greatly affects the quality of forecasting the value of investors' projects for the creation of a FC, and hence the efficiency of investment.

The question of assessing the value of project implementation, as well as its distribution among stakeholders, is devoted to a number of scientific works (Rachwan et al., 2016; Sydorchuk et al., 2016; Thomas et al., 2007; Tryhuba et al. 2016) and international standards (Bushuyev et al., 2010). These sciences refer to various applied spheres, the peculiarities of which affect the use of various methodological foundations. An analysis of these works, regarding the possibility of using the FC project for evaluating the value of investors, suggests that existing methods and models are characterized by many shortcomings. In particular, they do not take into account the peculiarities of the project environment of the drafting of the FC, which makes it impossible to substantiate the variable costs of feed production. In addition, they do not envisage the changing volumes of production and value of feed on the market, which greatly affects the quality of valuation of value for investors in the creation of FC projects.

Adequate prediction of the characteristics of the project environment and the determination of variable costs of funds for the production of feed is possible only on the basis of specific studies based on the simulation of the work on fodder production. It is quite labor intensive and requires the use of special computer programs (Sydorchuk et al., 2016). Due to the failure to account for project design specifics for each project, as well as without forecasting the changing costs of feed production and their market value, it is impossible to adequately assess the value of investors in the design of FC projects.

Scientific works (Sydorchuk et al., 2016; Tryhuba et al., 2016; Tryhuba et al., 2013; Tryhuba et al., 2011) relating to the draft FC, partly take into account the characteristics of their project environment and provide for the definition of the cost of funds for the production of feed based on the simulation of the implementation of the relevant works. However, the characteristics of the project environment of the draft FC are considered deterministic values, which does not fully reflect their reality. In addition, they do not take into account the variable market value of feed, which does not allow to adequately assess the value of investors in the creation of FC projects (Konečný et al., 2015).

In order to objectively assess the value of investors in FC projects, a model and computer program that takes into account the changing components of the project environment, based on the use of probability theory and methods of mathematical statistics, as well as modeling of the work to determine the variable costs of feed production should be developed. This is at the basis of a qualitative assessment of the risk of investors' value for the creation of FC projects (Tryhuba et al., 2018).

The purpose of the article is to develop a model for assessing the risk of investors' value for the creation of a FC and on the basis of a computer program, as well as conducting research on the impact of changing components of the project environment on the risk of the value of investors in these projects.

To achieve this goal the following tasks should be solved:

- To develop a model and computer program for evaluating the risk of investors' value in the creation of FC projects.

- For a given territorial community to investigate the changing characteristics of the project environment of the FC drafting projects and to justify the distribution of the estimated costs of feed production and their market value.

- For a given project environment and requirements (given minimum profit), investors of the projects of creation of the FC to determine the statistical characteristics of the distribution of their value and the degree of risk of its receipt.

\section{MATERIALS AND METHODS}

The value of investors in the creation of FC projects is characterized by profits $\left(\Pi_{r}\right)$ from the 
use of the product (FC). In this case, the quantitative value of profit $\left(\Pi_{r}\right)$ from year to year is variable, which determines the assessment of its risk. The quantitative value of the profit $\left(\Pi_{r}\right)$ from the functioning of the FC is influenced by the changing costs of feed production $\left(B_{r}\right)$ and the annual change in their selling price (Babenko et al., 2017; Tryhuba et al., 2016; Geman, 2008). When making managerial decisions regarding the appropriateness and volume of investments in the FC drafting projects, the risks to the investor should be weighed against the quantitative justification of the profit risk $R\left(\Pi_{r}\right)$ (Beranová et al., 2009).

The profit $\left(\Pi_{r}\right)$ from the product of the project creation of the FC, according to the r-th configuration, is defined as the difference between the market value $\left(C_{r}\right)$ of feed and the cost $\left(B_{r}\right)$ of their production:

$\Pi_{r}=C_{r}-B_{r}$,

where $\left(\Pi_{r}\right)$ - the profit received by investors of the Criminal Code, UAH; $\left(C_{r}\right)$ - market value of feed, UAH; $\left(B_{r}\right)$ - costs of feed production for a given configuration of the product of the project creation of the CK, UAH.

The market value $C_{r}$ of feed depends to a large extent on the market situation, demand for feed in the country and abroad, the level of yield of forage crops, the quality of feed, etc. Consequently, the market value $C_{r}$ of feed should be taken into account as a probabilistic value and evaluated on the basis of statistical data. Using methods of probability theory and mathematical statistics will enable to justify the law of distribution of market value $C_{r}$ of forages and to determine its main characteristics - mathematical expectation $M\left(C_{r}\right)$, mean square deviation $\sigma\left(C_{r}\right)$; variance $D\left(C_{r}\right)$, coefficient of variation $v\left(C_{r}\right)$ and density $f\left(C_{r}\right)$.

The costs $\left(B_{r}\right)$ of feed production depend to a large extent on the configuration of the product of the design of the FC (feed production, technology, technical equipment, resource costs, etc.) and the characteristics of the project environment (areas of fields, their territorial location, state and climatic conditions), etc. Taking this into account, the costs $\left(B_{r}\right)$ of feed production should be considered as probabilistic and assessed on the basis of simulation modeling of the products of the FC project creation projects for the predicted probable characteristics of their design environment. Using methods of probability theory and simulation modeling will allow to substantiate the law of distribution of costs $\left(B_{r}\right)$ for feed production and to determine its main characteristics - mathematical expectation $M\left(B_{r}\right)$, mean square deviation $\sigma\left(B_{r}\right)$; variance $D\left(B_{r}\right)$, coefficient of variation $v\left(B_{r}\right)$ and density $f\left(B_{r}\right)$ (Villa et al., 2016).

As mentioned above, the profit $\left(\Pi_{r}\right)$ from the FC is determined by the expression (1). It is received by investors of the projects of creation of the CC, provided that the market value $\left(C_{r}\right)$ of feed is greater than the cost $\left(B_{r}\right)$ of their production. Consequently, the risk of profit $R\left(P_{r}\right)$ can be written as:

$R\left(\Pi_{r}\right)=P\left(C_{r}>B_{r}\right)=P\left(C_{r}-B_{r}>0\right)$,

where $P\left(C_{r}>B_{r}\right)$ - the probability of the onset of the desired event (profit $\left(\Pi_{r}\right)$ ), or $P\left(C_{r}-B_{r}>0\right)$.

There are several scenarios for the formation of the value of investors for the creation of FC projects (the definition of profit risk $R\left(\Pi_{r}\right)$ ) in terms of the known density of distribution of costs $f\left(B_{r}\right)$ for feed production and their market value $f\left(C_{r}\right)$. Let's consider possible variants of formation of value of investors of projects of creation of spacecraft (Fig. 1).

The first option (Fig. 1, a) shows that in such a scenario, the formation of the value of investors in the creation of FC projects, there is no risk of profit. That is, investors, regardless of the quantitative value of feed costs $\left(B_{r}\right)$ and their market value $\left(C_{r}\right)$, earn investors profit $\left(\Pi_{r}\right)$.

The second option (Fig. 1, b) shows that in such a scenario, the formation of the value of investors in the creation of FC projects has a risk of profit. The shaded area, which has its floor area of distribution of costs $f\left(B_{r}\right)$ for the production of feed and its market value $f\left(C_{r}\right)$, characterizes the probability of non-receipt of profit. Since in this area the costs $f\left(B_{r}\right)$ of feed production may be higher than their market value $f\left(C_{r}\right)$, there is a loss. That is, depending on the quantitative value of the costs of feed production and their market value $\left(C_{r}\right)$, the risk of obtaining profit $\left(\Pi_{r}\right)$ by investors is determined.

The third variant (Fig. 1, c) shows that in such a scenario, the formation of the value of investors in the creation of FC projects, they will receive losses irrespective of the quantitative value of the costs $\left(B_{r}\right)$ of feed production and their market value $\left(C_{r}\right)$.

Let's consider a more detailed version of the scenario of the formation of the value of investors of projects for the creation of FC, which is characterized by risk (probability of profit $\left(\Pi_{r}\right)$ ) (Fig. 1, b). The probability that some value of the $\operatorname{cost}\left(B_{r}\right)$ of feed production is in a small (elementary) interval in width $d B_{r}$ is equal to the area of the element $d B_{r}$, that is:

$P\left(B_{0}-\frac{d B_{r}}{2} \leq B_{r} \leq B_{0}+\frac{d B_{r}}{2}\right)=f\left(B_{r}\right) d B_{r}$.

The probability that the market value $\left(C_{r}\right)$ of fodder exceeds in some variants the value of the costs $\left(B_{r}\right)$ of their production, can be written in the expression:

$P\left(C_{r}>B_{0}\right)=\int_{B_{0}}^{\infty} f\left(C_{r}\right) d C_{r}$.

The probability that the value of feed costs $\left(B_{r}\right)$ is in the range $d B$ and the market value $\left(C_{r}\right)$ of feed 
is higher than the costs $B_{r}$ given at this interval, provided that the random variables $C_{r}$ and $B_{r}$ are independent, has the form:

$$
f\left(B_{0}\right) d B_{r}=\int_{B_{0}}^{\infty} f\left(C_{r}\right) d C_{r} .
$$

In this case, the risk of profit $R\left(\Pi_{r}\right)$ is the likelihood that the market value $\left(C_{r}\right)$ of fodder is more costly $\left(B_{r}\right)$ for their production for all possible costs and therefore can be written:

$R\left(\Pi_{r}\right)=\int_{-\infty}^{\infty} f\left(B_{r}\right)\left[\int_{B_{0}}^{\infty} f\left(C_{r}\right) d C_{r}\right] d B_{r}$.
The probability of profit $P\left(\Pi_{r}\right)$ can also be calculated based on the fact that the costs $\left(B_{r}\right)$ of feed production will be less than their market $\left(C_{r}\right)$ value, the probability that the values $C_{r}$ are in a small interval $d C_{r}$ is determined by the expression:

$P\left(C_{0}-\frac{d C_{r}}{B_{r}} \leq C_{r} \leq C_{0}+\frac{d C_{r}}{B_{r}}\right)=f\left(C_{r}\right) d C_{r}$.

where $C_{0}$ - some given value of the market value of feed (current).

At the same time, the probability that the costs $\left(B_{r}\right)$ of feed production are less than their market $\left(C_{r}\right)$ value is as follows:

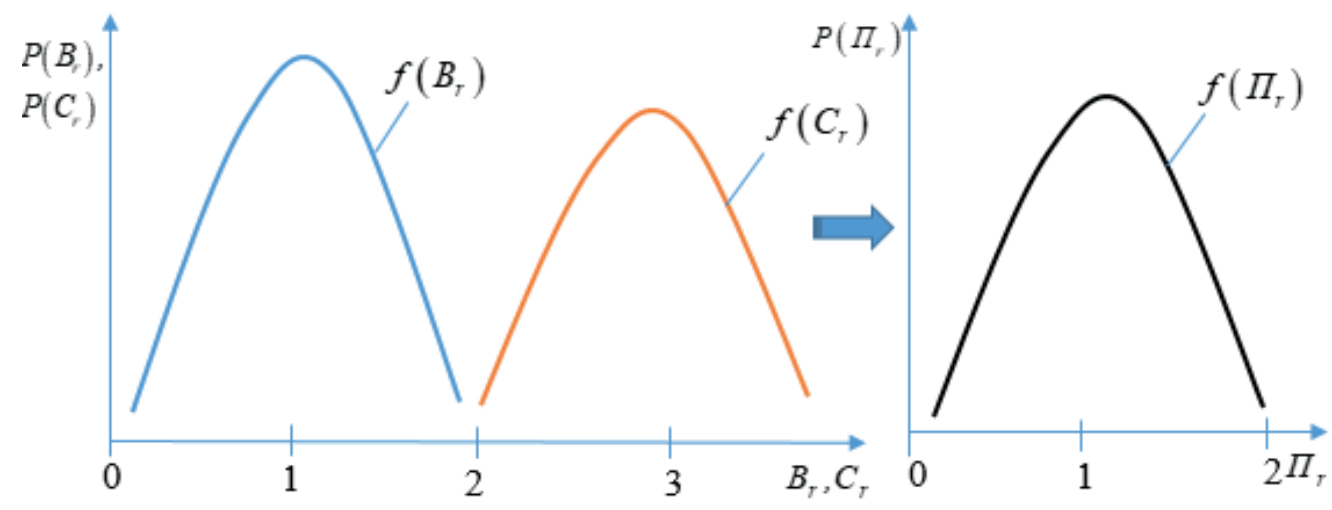

a)
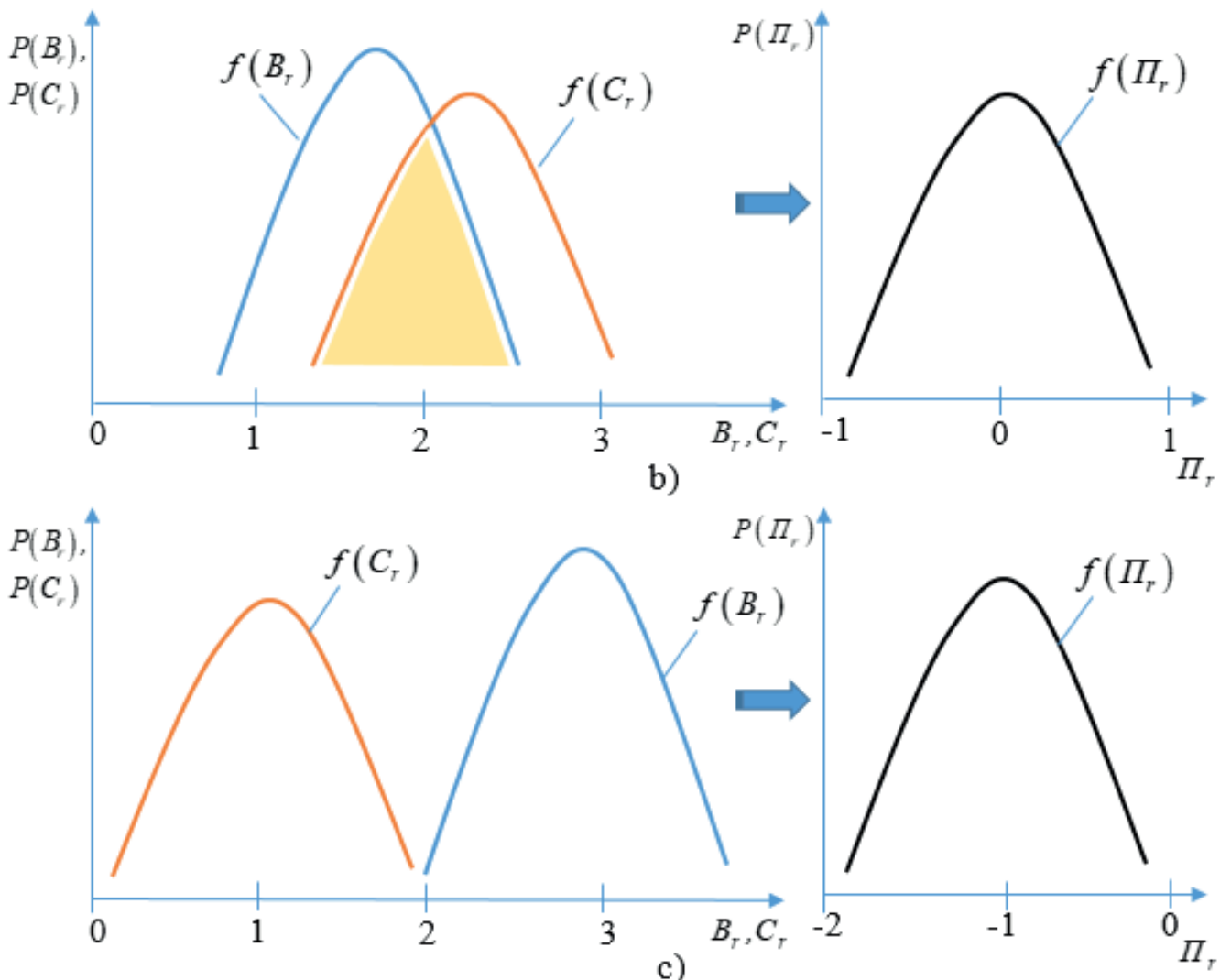

1: Variants of scenarios for the formation of the value of investors for the projects of creation of the CAC: there is no risk of profit (a), existing risk of profit (b), no profit (loss) (c) 


$$
P\left(B_{r} \leq C_{0}\right)=\int_{B_{0}}^{C_{0}} f\left(B_{r}\right) d B_{r} .
$$

Assuming that the costs $\left(B_{r}\right)$ of feed production and their market value $\left(C_{r}\right)$ are independent random variables, we determine the probability that the values $C_{r}$ are in a small interval $d C_{r}$ and the values of costs $B_{r}$ do not exceed $B_{0}$ the following expression:

$$
f\left(C_{0}\right) d C_{r}=\int_{-\infty}^{C_{0}} f\left(B_{r}\right) d B_{r} .
$$

Consequently, the probability of profit for investors in the creation of QC projects for all values of the market value $\left(C_{r}\right)$ of feed is as follows:

$$
R\left(\Pi_{r}\right)=\int_{-\infty}^{\infty} f\left(C_{r}\right)\left[\int_{-\infty}^{C_{r}} f\left(B_{r}\right) d B_{r}\right] d C_{r} .
$$

On the basis of equations (6) and (10), we can determine the risk of loss $R\left(3_{r}\right)$, which we describe by expression:

$R\left(3_{r}\right)=1-R\left(\Pi_{r}\right)=P\left(C_{r} \leq B_{r}\right)$.

Substituting in (11) the expression for $R\left(\Pi_{r}\right)$ the formula (6), we obtain:

$$
\begin{aligned}
& R\left(3_{r}\right)=P\left(C_{r} \leq B_{r}\right)=1-\int_{-\infty}^{\infty} f\left(B_{r}\right)\left[\int_{B_{0}}^{\infty} f\left(C_{r}\right) d C_{r}\right] d B_{r}= \\
& =1-\int_{-\infty}^{\infty} f\left(B_{r}\right)\left[1-F\left(B_{r}\right)\right] d B_{r}=\int_{B_{0}}^{\infty} F\left(B_{r}\right) f\left(B_{r}\right) d B_{r}
\end{aligned}
$$

where $F\left(B_{r}\right)$ - the distribution function of the quantitative value of the costs $\left(B_{r}\right)$ of feed production.
In addition, on the basis of equation (10), we can write:

$$
\begin{aligned}
& R\left(3_{r}\right)=P\left(C_{r} \leq B_{r}\right)=1-\int_{-\infty}^{\infty} f\left(C_{r}\right)\left[\int_{-\infty}^{C_{r}} f\left(B_{r}\right) d B_{r}\right] d C_{r}= \\
& =1-\int_{-\infty}^{\infty} f\left(C_{r}\right) F\left(C_{r}\right) d C_{r}=1-\int_{-\infty}^{\infty}\left[1-F\left(C_{r}\right)\right] f\left(C_{r}\right) d C_{r},
\end{aligned}
$$

where $F\left(C_{r}\right)$ - the distribution function of the quantitative value of the market value of feed $C_{r}$.

On the basis of the above described, it is possible to distinguish three zones of formation of the value of investors of projects of creation of FC, which characterize the losses (lack of profit) (I), the given minimum profit (II) and profit (III) (Fig. 2).

To determine the probability that a profit $\Pi_{r}$ will be greater than a given value $\Pi_{3}$, it is necessary to find the distribution density of the random value of profit $f\left(\Pi_{r}\right)$.

On the basis of equation (1) and assuming that the random quantitative values $C_{r}$ and $B_{r}$ are independent and inseparable, the distribution density of the random value of profit $f\left(\Pi_{r}\right)$ has the form:

$$
\begin{aligned}
& f\left(\Pi_{r}\right)=\int_{B_{r}}\left(C_{r}-B_{r}\right) f\left(B_{r}\right) d B_{r}= \\
& =\left\{\begin{array}{l}
\int_{0}^{\infty} f\left(C_{r}-B_{r}\right) f\left(B_{r}\right) d B_{r}, \quad \Pi_{r} \geq 0 \\
\int_{-P}^{\infty} f\left(C_{r}-B_{r}\right) f\left(B_{r}\right) d B_{r}, \quad \Pi_{r} \leq 0
\end{array}\right.
\end{aligned}
$$

From the above, it follows that the risk of profit $R\left(\Pi_{r}\right)$ can be expressed by the expression:

$$
R\left(\Pi_{r}\right)=\int_{0}^{\infty} f\left(\Pi_{r}\right) d \Pi_{r}=\int_{0}^{\infty} \int_{0}^{\infty} f\left(C_{r}-B_{r}\right) d C_{r} d B_{r} .
$$

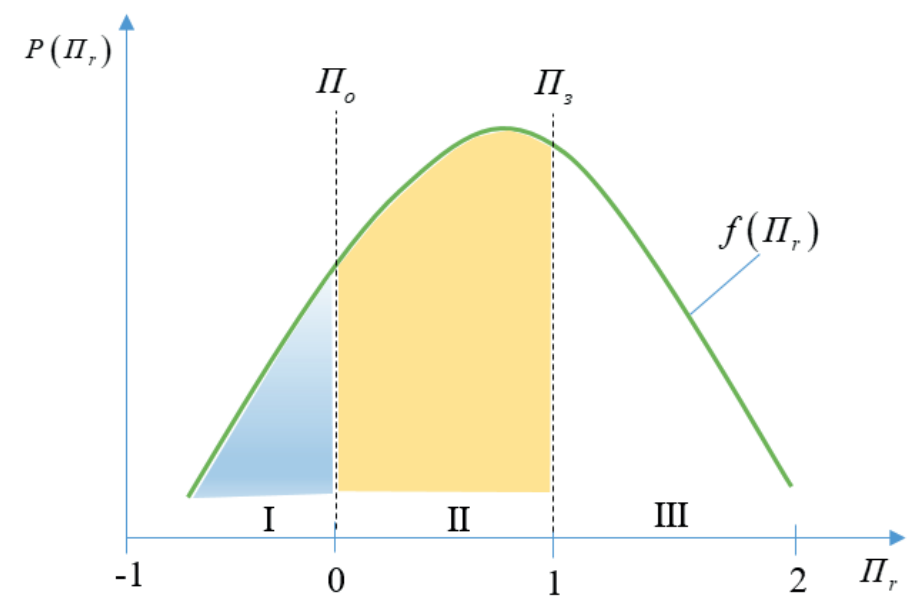

2: Formation of the risk of investors' value in drafting FC: I-zone of loss (no profit), II - zone of the given minimum profit, III - zone of profit, $\Pi_{0}$, $\Pi_{3}$-respectively, zero and given the minimum profit of the investor 
The risk that a profit $\Pi_{r}$ will be greater than a given value $\Pi_{3}$ will be:

$$
R\left(\Pi_{3}<\Pi_{r}<\infty\right)=\int_{\Pi_{3}}^{\infty} f\left(\Pi_{r}\right) d \Pi_{r} .
$$

The risk of losses $R\left(3_{r}\right)$ can be written by the following equation:

$$
R\left(3_{r}\right)=\int_{-\infty}^{0} f\left(\Pi_{r}\right) d \Pi_{r}=\int_{-\infty}^{\Pi_{0}} \int_{-\Pi_{r}}^{\infty} f\left(C_{r}-B_{r}\right) d C_{r} d B_{r} .
$$

\section{RESULTS AND DISCUSSION}

In order to assess the risk of investors' value for the creation of cooperatives in the FC, statistics should be provided on the costs $\left(B_{r}\right)$ of producing feed and their market value $\left(C_{r}\right)$. In terms of costs $B_{r}$, they are variable and determined by a number of factors (Gonchar et al., 2014; Harčariková, 2018). To take into account the influence of a plurality of these factors on costs $B_{r}$ is possible only by simulating the implementation of work on feed production for SMF in a given project environment (Kopečková et al., 2016; Máchal, 2009; Shorikov et al., 2014).

The initial data for simulation of the work on feed production for SMF were the results of the study of the characteristics of the design environment for the conditions of the «Pokrov» Brody District of the Lviv region, which serves 185 heads of dairy herd with an average milk yield of $5500 \mathrm{~kg} / \mathrm{year}$.

In order to provide the dairy herd with food during the winter period and to feed its green fodder in the summer, crop rotation is recommended, which includes the following fields: 1 - annual grasses, with sowing of perennial herbs; 2-3 - perennial grasses in the hay; 4 - perennial herbs in the haylage; 5 - corn silage; 6 - annual grass on green feeds. For calculations of natural resources (areas of fields under feed crops), the average value of crop yield of forage crops in the Lviv region is adopted, in particular: perennial herbs in hay - $45 \mathrm{c} / \mathrm{ha}$; perennial herbs in the haylage - 90 centners/ha; corn on silage - 225 c/ha; annual grass on green feed - $180 \mathrm{c} / \mathrm{ha}$; pastures $70 \mathrm{c} / \mathrm{ha}$.

The basis of the simulation modeling of the work on the production of forages for SMF is the technological regulations relating to the existing progressive technologies for the cultivation of fodder crops [22]. Given that the SMF is small (with a dairy herd up to 200 heads), the configuration objects (technical equipment) of the creation of the SMF are selected from low-power energy. For the basic power means for production of feed the domestic tractor KhTZ-3512 with the necessary agricultural machines is taken. To carry out the research, a computer program was used, the window with the initial data is shown in Fig. 3.

Having performed the simulation of the implementation of feed production on the changing characteristics of the project environment (the length of the periods of holding the dairy herd, the yield of forage crops), received the main system functional indicators: the cost of resources for the work on individual feed crops, the duration of the use of energy and agricultural machinery, the

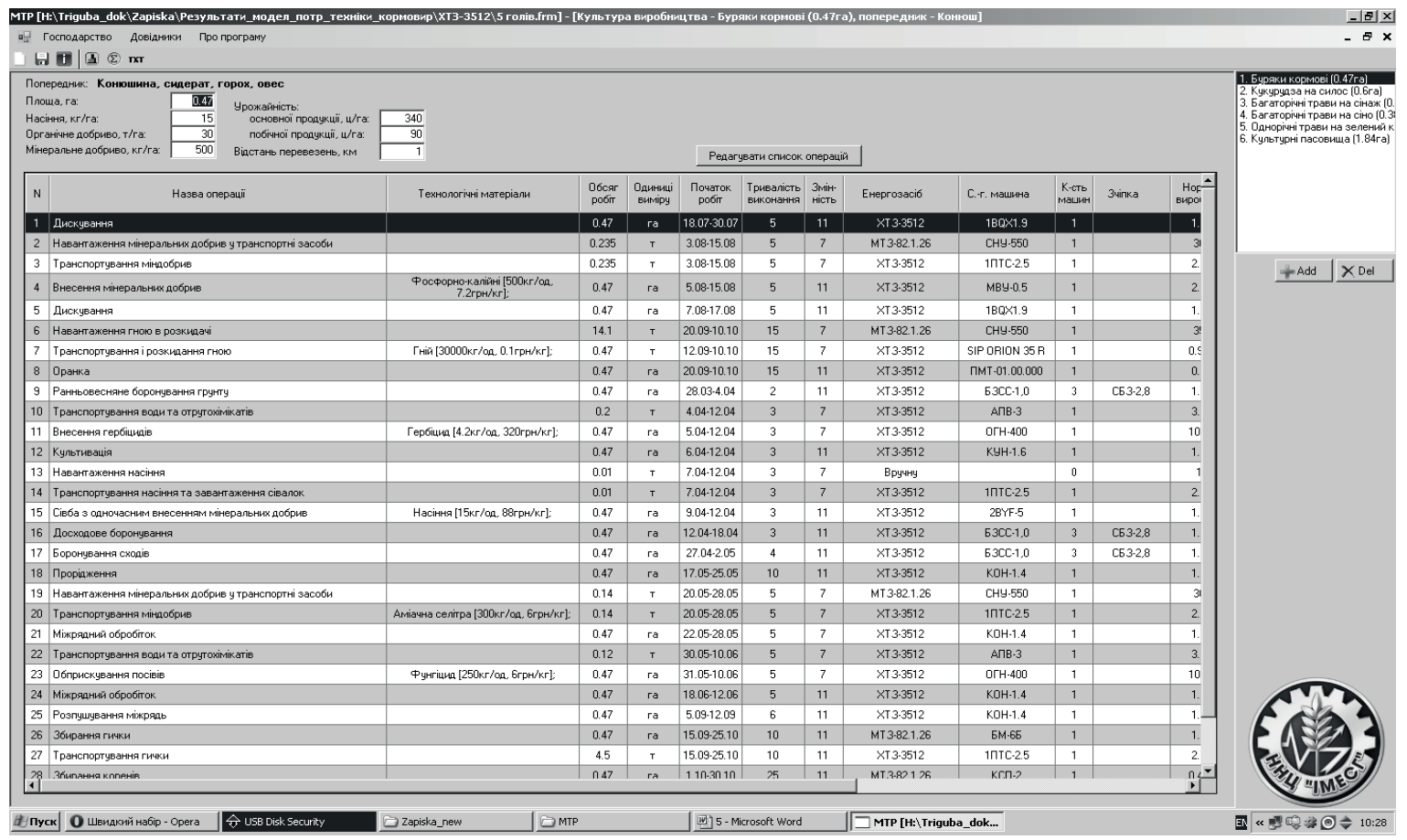

3: Window with initial data of the computer program of simulation of the implementation of work on feed production 
I: Results of substantiation of the initial data for assessing the risk of investors' value in the creation of FC projects

\begin{tabular}{lcccr}
\hline \multicolumn{1}{c}{ The name of indicator } & $\begin{array}{c}\text { The law } \\
\text { of distribution }\end{array}$ & \begin{tabular}{c} 
Math \\
\cline { 3 - 4 }
\end{tabular} & Statistical characteristics \\
\hline $\begin{array}{l}\text { Expenses }\left(B_{r}\right) \text { on feed } \\
\text { production, thousands, UAH }\end{array}$ & Normal & 884.3 & $\begin{array}{c}\text { Median } \\
\text { deviation }\end{array}$ & $\begin{array}{c}\text { Coefficient } \\
\text { of variation }\end{array}$ \\
$\begin{array}{l}\text { Market value }\left(C_{r}\right) \text { of feed, } \\
\text { thousands, UAH }\end{array}$ & Normal & 1143.4 & 167.3 & 27989.29 \\
\hline
\end{tabular}

need in power tools and agricultural machines, the need for executives. On their basis, the statistical characteristics of the distribution of expenses $\left(B_{r}\right)$ for production of forages, taking into account the prices of equipment, consumables and salary as of 01.01.2018, were determined. The results obtained are presented in Tab. I.

Based on official statistics on feed costs in the western region of Ukraine, quantitative values of the market value of forages $\left(C_{r}\right)$ and statistical indicators that characterize its variability are substantiated. The results obtained are presented in Tab. I. The obtained data was processed using mathematical statistics methods, which established that they are represented by the normal theoretical distribution laws with differential functions:

$$
\begin{aligned}
& f\left(B_{r}\right)=2.39 \cdot 10^{-3} \cdot \exp \left[-\frac{\left(B_{r}-884.3\right)^{2}}{5.59 \cdot 10^{4}}\right] . \\
& f\left(C_{r}\right)=1.57 \cdot 10^{-3} \cdot \exp \left[-\frac{\left(C_{r}-884.3\right)^{2}}{1.28 \cdot 10^{5}}\right] .
\end{aligned}
$$

The numerical characteristics of these distributions are respectively: mathematical expectations - 884.3 and 1143.4 thousand UAH; average deviation - 167.3 and 253.4 thousand UAH. The limits of changes in the costs $\left(B_{r}\right)$ of feed production and the market value of feed $\left(C_{r}\right)$, respectively, are $703 \ldots 1053$ and $912 \ldots 1402$ thousand UAH.

Consequently, presented in the Tab. I results indicate that for production of feed in the "Pokrova", Brody district, Lviv region, for 185 heads of dairy herds milk yield $5500 \mathrm{~kg} / \mathrm{year}$, the mathematical expectation of the cost $M\left(B_{r}\right)$ of their production is smaller than the mathematical expectation of their value in the marke $M\left(C_{r}\right)$ for 259,1 thousand UAH. The data obtained are the basis for assessing the risk of investors' value in projects for the creation of cooperatives of the FC.

For the purpose of qualitative and quick assessment of the risk of investors' value for the creation of QC projects based on a well-founded model, a corresponding computer program has been developed in Python (Fig. 4).

The assessment of the risk of the value of investors to the projects of the creation of the FC was carried out for the conditions of the "Pokrov" of the Brody district of the Lviv region, which will serve 185 heads of dairy herds with an average milk yield of $5500 \mathrm{~kg} /$ year.

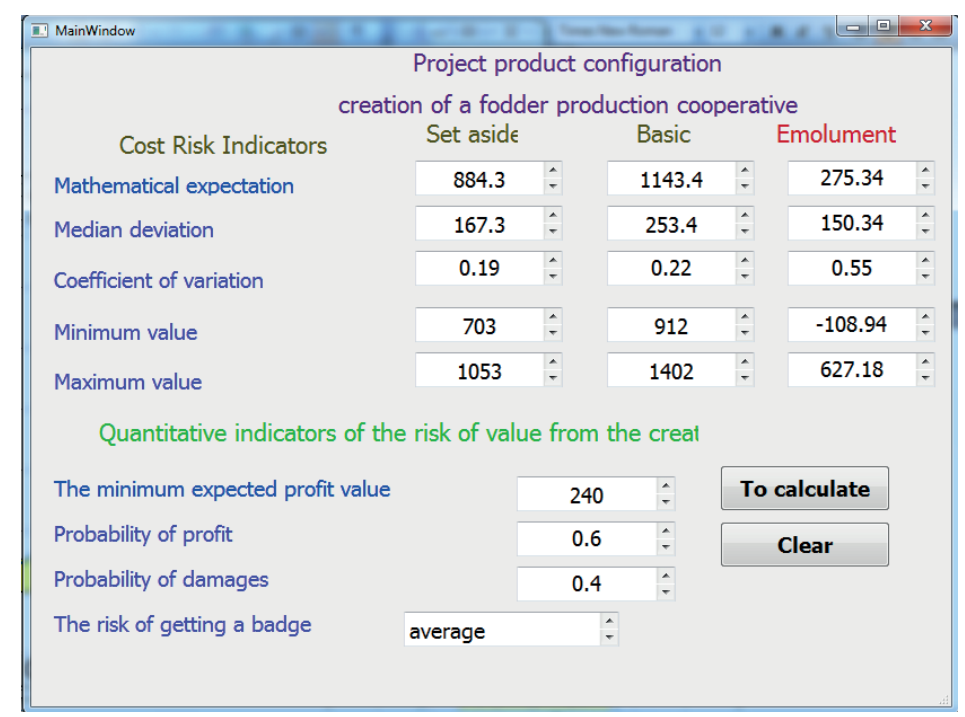

4: Window of the computer program evaluating the risk of the value of investors in the creation of FC projects 


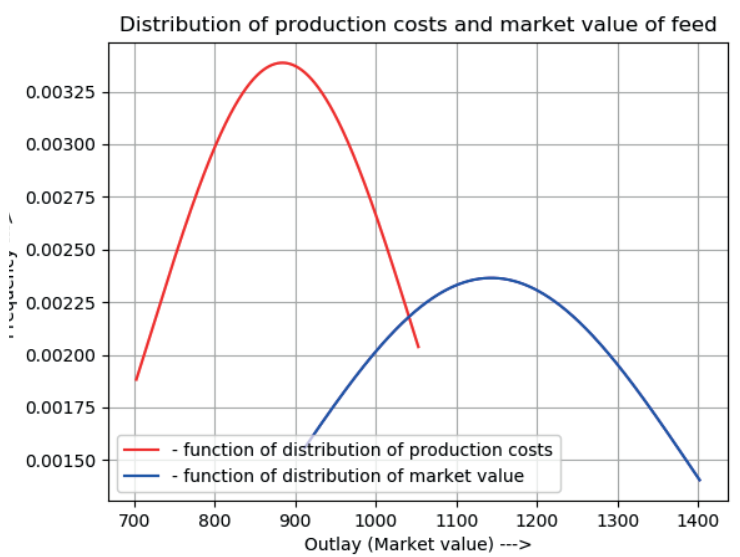

a)

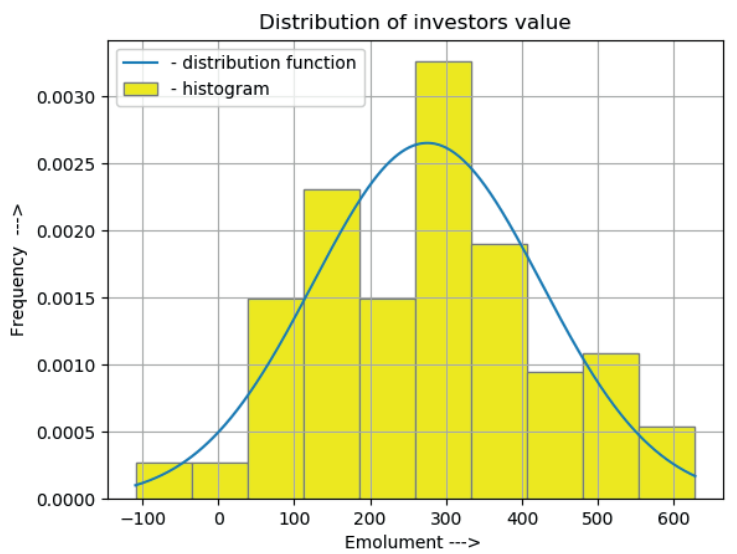

b)

5: Differential functions of distribution of expenses $\left(B_{r}\right)$ for feed production and their market value $\left(C_{r}\right)(a)$ and a histogram and a differential function of distribution of profits ( $\left.\Pi_{r}\right)$ of investors (b)

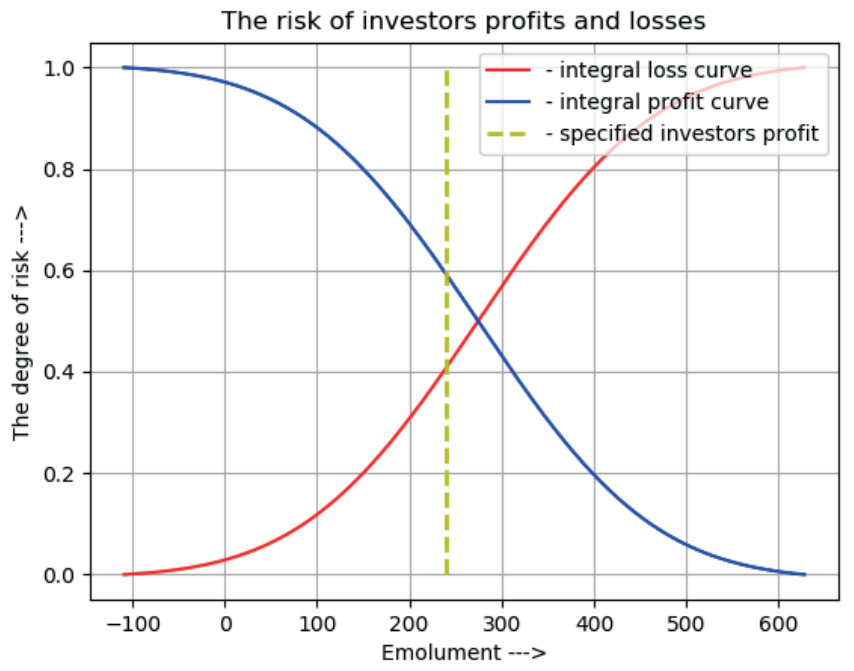

6: Integral curves of profits $\left(\Pi_{r}\right)$ and losses $\left(\Pi_{r}\right)$ of investors of the FC

A computer program for evaluating the risk of the value of investors in the creation of QC projects (see Fig. 4) has been developed, based on the given statistical characteristics of the distribution of costs $\left(B_{r}\right)$ for feed production and their market value $\left(C_{r}\right)$ (see Tab. I), provides for the construction of their distribution functions (Fig. 5, a), as well as performs calculations of statistical characteristics of the distribution $\left(\Pi_{r}\right)$ of investors' income and the construction of its histogram and distribution functions (Fig. 5, b).

It is established that the profit $\left(\Pi_{r}\right)$ of investors of the projects of creation of the FC is reflected by the normal theoretical distribution law with a differential function:

$f\left(\Pi_{r}\right)=2.57 \cdot 10^{-3} \cdot \exp \left[-\frac{\left(\Pi_{r}-276.02\right)^{2}}{4.8 \cdot 10^{4}}\right]$.

Numerical characteristics of distribution of profit $\left(\Pi_{r}\right)$ of investors of FC are as follows: mathematical expectation - 275,34 thousand UAH; average deviation - 150.34 ths. UAH. The boundaries of changes in the profit $\left(\Pi_{r}\right)$ of investors FC is $-108.94 \ldots$ 627.18 thousand UAH.

In addition, the computer program was developed (see Fig. 4), performs appropriate calculations and constructs integrated curves of profits $F\left(\Pi_{r}\right)$ and losses $F\left(3_{r}\right)$ of investors, for the given minimum value of their profit $\left(\Pi_{3}\right)$ (Fig. 6).

It is established that profits $\left(\Pi_{r}\right)$ and losses $\left(3_{r}\right)$ of investors of FC are described by integral functions:

$F\left(\Pi_{r}\right)=2.57 \cdot 10^{-3} \cdot \int_{0}^{627} \exp \left[-\frac{\left(\Pi_{r}-275.34\right)^{2}}{4.8 \cdot 10^{4}}\right] d \Pi_{r}$.

$F\left(3_{r}\right)=1-\left(2.57 \times 10^{-3} \cdot \int_{-108.94}^{0} \exp \left[-\frac{\left(\Pi_{r}-275.34\right)^{2}}{4.8 \times 10^{4}}\right] d \Pi_{r}\right)$. 
At the same time, the value of investors FC, for a given minimum value of their profit $\left(\Pi_{3}=240\right.$ thousand UAH), the integral function:

$$
F\left(\amalg_{\kappa \kappa}\right)=2.57 \cdot 10^{-3} \cdot \int_{240}^{627} \exp \left[-\frac{\left(\Pi_{r}-275.34\right)^{2}}{4.8 \cdot 10^{4}}\right] d \Pi_{r} .
$$

The obtained integral functions (21-23) indicate that the value of investors FC for a given minimum value of their profit $\left(\Pi_{3}=240\right.$ thousand UAH), obtained with a degree of risk equal to 60\%. This suggests that investing in such a project has an average risk of receiving a given profit.

The results of the research show that determining the value of investors in the design of FC projects should be taken into account the risk of the costs of feed production and their market value. A computer program developed for this model and on the basis of it, makes it possible to take into account the mentioned changing components and to substantiate the patterns of profit change for the investors of the mentioned cooperatives. In addition, the proposed management decision making tool improves quality and speeds up management decisions by justifying the level of risk of obtaining value from investments in FC drafting projects with a given minimum value of their profits.

Implementation of projects for the establishment of family dairy farms to enhance the food security of the state, requires the simultaneous implementation of projects for the creation of cooperatives for their forage. However, there is a scientific and applied task of assessing the risk of investors' value for these projects, which requires the development of a model and computer program for improving the quality and speeding up of management decisions.

A model for assessing the risk of the value of investors for the projects of providing forage family dairy farms and on the basis of a computer program, taking into account the changing components of the project environment of these projects, is based on the use of the theory of probabilities and methods of mathematical statistics, as well as modeling of work execution for the determination of variable costs for feed production, which ensures high-quality and quick definition of risk taking into account requirements (given minimum profit) of investors (Jain et al., 2018; Klegová et al., 2015; Konečný et al., 2015).

\section{CONCLUSION}

Based on the simulation modeling of the work on feed production and the use of mathematical statistics methods, the initial data for assessing the risk of investors' value in projects for the establishment of cooperatives forage feeding of family dairy farms, suggest that for the production of feed in the cooperative of the "Pokrova" Brody district Lviv region for 185 heads of dairy herd milk productivity $5500 \mathrm{~kg} / \mathrm{year}$ The costs of their production and their market value are described by normal distribution laws. At the same time, the mathematical expectation of the costs $M\left(B_{r}\right)$ of feed production is smaller compared to the mathematical expectation of their value in the market $M\left(C_{r}\right)$ at 259.1 thousand UAH. The obtained statistical data are the basis for estimating the risk of investors' value in projects for the creation of cooperatives forage for family dairy farms.

It is substantiated that the profit of the investors of the project of establishing a cooperative forage for family dairy farms for the conditions of the "Pokrov" is described by the normal distribution law, which has the following characteristics: mathematical expectation - 275,34 thousand UAH; average deviation - 150.34 thousand UAH. The limits of this profit change are $-108.94 \ldots 627.18$ thousand $\mathrm{UAH}$.

Based on the received integral functions (21-23), the profit, loss and value of investors of the cooperative of forage provision of family dairy farms for the given minimum value of their profit $\left(\Pi_{3}=240\right.$ thousand UAH), it is established that the indicated value is obtained with a degree of risk equal to 60\%. This suggests that investing in such a project has an average risk of receiving a given profit of investors.

\section{Acknowledgements}

The presented work was performed in accordance with the research development "Development of project-led innovative systems, resource-saving technologies and technical means in agroindustrial production and its energy supply” (state registration number: 0106 U 002075). Fundet by Ministry of Education and Science of Ukraine. 


\section{REFERENCES}

BABENKO, V., ROMANENKOV, Y., YAKYMOVA, L. et al. 2017. Development of the model of minimax adaptive management of innovative processes at an enterprise with consideration of risks. EasternEuropean Journal of Enterprise Technologies, 5/4(89): 49-56.

BERANOVÁ, M. and MARTINOVIČOVÁ, D. 2009. Modelling of cost-functions under risk and uncertainty. Acta univ. agric. et silvic. Mendel. Brun., 57(3): 13-20.

BUSHUYEV, S. and BUSHUYEVA, N. 2010. Mechanisms of formation of value in the activities of projectmanaged organizations [in Russian: Механизмы формирования ценности в деятельности проектно-управляемых организаций]. East-European Journal of Advanced Technology, 1/2(43): 4-9.

BUSHUYEV, S. and KHARITONOV, D. 2010. Valueable approach in the management of the development of complex systems [in Russian: Ценностный подход в управлении развитием сложных систем]. Управління розвитком складних систем, 1: 10-15.

GEMAN, H. 2008. Risk Management in Commodity Markets: From Shipping to Agriculturals and Energy. Chichester: John Wiley \& Sons Ltd.

GONCHAR, N. 2014. Dynamical Risk Model with Investment in Assets. Journal of Automation and Information Sciences, 46(5): 15-34.

HARČARIKOVÁ, M. 2018. Managing Price Risk in the Corn Market Using Option Strategies. Acta Universitatis Agriculturae et Silviculturae Mendelianae Brunensis, 66(3): 767-779.

JAIN, P., PASMAN, H., WALDRAM, S. et al. 2018. Process Resilience Analysis Framework (PRAF): A systems approach for improved risk and safety management. Journal of Loss Prevention in the Process Industries, 53: 61-73.

KLEGOVÁ, J. and RÁBOVÁ, I. 2015. Enterprise Content Management Implementation and Risk. Acta Universitatis Agriculturae et Silviculturae Mendelianae Brunensis, 63(5): 1687-1695.

KONEČNÝ, Z. and ZINECKER, M. 2015. Measuring Risk Structure Using the Capital Asset Pricing Model. Acta Universitatis Agriculturae et Silviculturae Mendelianae Brunensis, 63(1): 227-233.

KONEČNÝ, Z. and ZINECKER, M. 2016. Optimizing Risk Structure in Connection with the Corporate Life Cycle and Sector Cyclicity. Acta Universitatis Agriculturae et Silviculturae Mendelianae Brunensis, 64(3): 949-959.

KOPEČKOVÁ, M. and MÁCHAL, P. 2016. Survey on the Level of Knowledge and Skills of Project Managers in Regional Development. Acta Universitatis Agriculturae et Silviculturae Mendelianae Brunensis, 64(4): 1325-1335.

MÁCHAL, P. 2009. Possibilities of application of process modelling when developing a proposal of the business process management system for a university department. Acta univ. agric. et silvic. Mendel. Brun., 57(2): 61-68.

RACHWAN, R., ABOTALEB, I. and ELGAZOULI, M. 2016. The Influence of Value Engineering and Sustainability Considerations on the Project Value. Procedia Environmental Sciences, 34: 431-438.

SHORIKOV, A. and BABENKO, V. 2014. Optimization of assured result in dynamical model of management of innovation process in the enterprise of agricultural production complex. Economy of Region, 1(37): 196-202.

SYDORCHUK, O., TRYHUBA, A. and SYDORCHUK L. 2016. Engineering of cooperative production of dairy products: system-project bases [in Ukrainian: Інженерія кооперованого виробництва молочної продукції : системно-проектні основи]. Nizhyn: Publisher PE Lysenko MM.

TESLYA, Y., OBEREMOK, I. and OBEREMOK N.V. 2016. Value-homeostatic approach to the evaluation of solutions for the project. Management of the development of complex systems, 25: 73-79.

THOMAS, J. and MULLALY, M. 2007. Understanding the Value of Project Management: First Steps on an International Investigation in Search of Value. Project Management Journal, 38(3): 74-89.

TRIHUBA, A., SIDORCHUK, L., SHELEGA, O. et al. 2015. Management of the value of projects of technical and technological service cooperatives. Motorization and energetics in agriculture, 17(3): 160-166.

TRYHUBA, A. and SHOLUDKO, P. 2011. Coordination of works in integrated milk projects [in Ukrainian: Узгодження робіт у інтегрованих проектах молочарства]. Sci-European Journal of Advanced Technologies, 1/6(49): 13-16.

TRYHUBA, A. 2014. Argumentation of the parameters of the system of purveyance of milk collected from the private farm-steads within a single administratinve district. Econtechhod, 3(4): 23-27.

TRYHUBA, A. 2015. Justification of the Parameters of Dairy Farm Supply Systems. Motrol: Motorization and energetics in agriculture, 17(4): 81-88.

TRYHUBA, A., SHOLUDKO, P., MALANCHUK, O. et al. 2013. Formulation of vibro-technologic risk in integrating programs of agrarian production [in Ukrainian: Формування виробничо- 
технологічного ризику в інтегрованих програмах аграрного виробництва]. Sci-European Journal of Advanced Technologies, 1/10(61): 203-206.

TRYHUBA, A., SHOLUDKO, P., SYDORCHUK, L. et al. 2016. System-valued principles of management of integrated milking development programs on the basis of modeling [in Ukrainian: Системноціннісні засади управління інтегрованими програмами розвитку молочарства на основі моделювання]. Bulletin of the National Technical University "KhPI". Collection of scientific works. Series: Strategic Management, Portfolio Management, Programs and Projects, 2(1174): 103-107.

TRYHUBA, A., TRYHUBA, I., BOYARCHUK, O. et al. 2018. Identification of the design environment and projects for the provision of family dairy farms. Bulletin of the National Technical University "KhPI". Collection of scientific works. Series: Strategic Management, Portfolio Management, Programs and Projects, 1(1277): 64-68.

VASYLIEVA, N. 2016. Cluster models of households' agrarian production development. Economic Annals-XXI, 158(3-4(2)): 13-16.

VILLA, V., PALTRINIERI, N., KHAN, F. et al. 2016. Towards dynamic risk analysis: A review of the risk assessment approach and its limitations in the chemical process industry. Safety Science, 89: 77-93.

Contact information

Anatoliy Tryhuba: trianamik@gmail.com

Vitalij Boyarchuk: vim2@ukr.net

Inna Tryhuba: trinle@ukr.net

Oleh Boyarchuk: boyarchuko@ukr.net

Oksana Ftoma: oftoma@ukr.net 